УДК 165.62+801.73+111.852

DOI 10.35423/2078-8142.2020.2.2.06

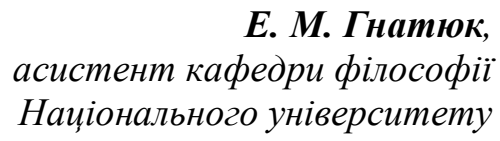
водного господарства та природокористування, м. Рівне, Україна e-mail:e.m.gnatyuk@nuwm.edu.ua ORCID: https://orcid.org/0000-0002-4128-2724

\title{
СИМВОЛ, ГРА І СВЯТО ЯК МОДАЛЬНОСТІ ЕСТЕТИЧНОГО В КОНТЕКСТІ ГЕРМЕНЕВТИЧНОГО ДОСВЦДУ
}

У статті обтрунтовується теза про те, щуо герменевтичний досвід Г.-Г. Гадамера є тотожним досвіду мистецтва, яке постає автономним джерелом «досвіду істини». Автор відзначає, що пошук критерїв художньої достовірності вимагає звернення до традиції формування фундаментальних естетичних категорій, серед яких, насамперед, символ, гра і свято. Символи як специфічні культурні коди, напрацьовані мистецтвом, апелюють до переломних моментів людської буттєвості, трансформуючи ї̈ духовну сутність. Доводиться, щуо перенесення уваги на «гру» демонструє реалізацію принцииу засадничого взаємозв'язку між філософією та сферою практики, завдяки чому твір мистецтва постає як актуальна присутність, сутність якої полягає у «постійному прирошуванні буття». Атмосферу співучасті з мистецтвом у Г.Г. Гадамера передає свято. Таким чином, експлікація герменевтичного досвіду з допомогою понять символ, гра та свято в естетичній концепиії Г.-Г. Гадамера дає можливість актуалізувати смислові иари, які містять у собі основні складові горизонту, щуо окреслює життєвий світ людини та розкриває досвід буття у cвimi.

Ключові слова: символ, гра, свято, герменевтика, естетика, розуміння, герменевтичний досвід.

(C) Гнатюк E. M., 2020 
На тлі розімкнутості художньо-історичного простору, множинності і взаємопроникнення різних художніх стилів, розширення контекстів людської буттєвості та їі духовних обріїв нині відбувається очевидне розширення герменевтичного досвіду, який у концепції Г.-Г. Гадамера постає як шлях від нерозуміння до розуміння, позначений тривалістю і процесуальністю. Виявлення повноти і достовірності означеного шляху орієнтує на виявлення щораз вищих смислових рівнів розуміння, в якому, згідно з Г.-Г. Гадамером, наявні два аспекти: «причетності до смислу», та наближення до цієї точки, яке підкреслює, що «справжній смисл тексту чи художнього твору ніколи повною мірою не вичерпується» [5, с. 353]. Відповідно, шлях герменевтичного досвіду доцільно інтерпретувати не як певну висхідну лінію, а як окремі точки розуміння, де кожна наступна буде випереджувати попередню за рівнем пережитого досвіду причетності до смислу, позаяк кожна попередня точка з погляду наступної свідчитиме більше про нерозуміння, як розуміння.

Важливо усвідомити, що герменевтичний досвід Г.Г. Гадамера, по-перше, базується одночасно як на розумінні, так $\mathrm{i}$ нерозумінні, по-друге, як незавершений, не передбачає фінальної точки розуміння. Як і М. Гайдеггер, Г.-Г. Гадамер відкидає логічно-інструментальне трактування розуміння, вписуючи його в онтологічний план, крізь призму якого розуміння стає способом людського буття. Герменевтичний проект Г.-Г. Гадамера суттєво трансформує і шлейєрмахерівське вчення про «мистецтво розуміння», $\mathrm{i}$ дільтеївський метод гуманітарного пізнання, в яких позиціонувала себе герменевтична традиція. Синтезуючи екзистенційнофеноменологічну філософію 3 вимогами герменевтики, Г.Г. Гадамер суттєво модифікує іiі цілі та завдання. Спираючись на вчення М. Гайдеггера про наявність дорефлексивних структур світу та їх «наперед-визначення», Гадамер розгортає версію «наперед-розуміння», що спільно $з$ історичною діалектикою тексту творить герменевтичне коло і більшою мірою, ніж розсудкові варіанти, визначає нашу причетність до світу і традиції. Зауважимо, що для Гадамера традиція $\epsilon$ «збереженням того, що є, збереженням, яке здійснюється за будь-яких історичних змін» [5, с. 334]. До традиції однаковою мірою причетні і передання, і реципієнт, а тому 
традиція є стержнем історії. Що ж до минулого, яке у часовому вимірі дистанційоване від нас, Гадамер вважає, що «за всіх обставин основним моментом нашого ставлення до минулого... є зовсім не дистанція від історичного передання і не свобода від нього, позаяк ми завжди перебуваємо всередині нього» [5, с. 335]. Отже, гадамерівський варіант герменевтичного досвіду, що містить наперед-розуміння, задається зсередини, поза зовнішніми впливами, таким чином, що внутрішній план буття ніколи не втрачає своєї актуальності, а «саме розуміння належить мислити швидше не як дію суб'єктивності, а як включення у звершення передання, де відбувається безперервне опосередкування минулого і теперішнього» [5, с. 345]. Показово, що дослідник апріорі відкидає розмаїття інтерпретацій і зосереджується на пошуку смислів, закладених у тексTi.

Герменевтичний досвід Г.-Г. Гадамера тотожній досвіду мистецтва, що постає автономним джерелом «досвіду істини» й репрезентує естетичне як один із трьох вимірів людського буття i трьох видів досвіду - естетичного, історичного та мовного, яким присвячено три розділи праці мислителя.

Естетичне у цьому контексті $є$ буттєвою домінантою сучасності й зумовлює процеси естетизації, які значно розширюють межі досвіду і пронизують усі сфери буття.

Художня реальність, перенасичена буденністю, постала перед проблемою власної «герменевтичної ідентичності», пошуку критеріїв художньої достовірності, що вимагає звернення до джерел людського досвіду, а у гадамерівському сенсі - традиції формування фундаментальних естетичних категорій, серед яких на першому плані - символ, гра і свято.

Підкреслимо, що художній текст для мислителя є «уламком буття», що прагне «поєднатися з відповідним йому уламком у гармонійну цілісність» [4, с. 299], і саме цей уламок $є$ фрагментом життя, без якого неможливо побачити відблиск істини. Зв'язок між уламками буття у Гадамера забезпечує символ, який не лише відсилає до значення, а й репрезентує та актуалізує його у мистецькому творі, що дає можливість донести до людини «послання блага і гармонії» [4, с. 299]. Саме за посередництвом символу автор реалі- 
зує ідею, недосяжну для безпосереднього споглядання, а символ акумулює у межах предметного образу повноту людського буття, стверджуючи його здійсненність та неповторність.

Трансформація гадамерівської концепції символу простежується у праці Ю. Лотмана «Символ у культурі», де в семіотичній інтерпретації символ постає як «послання інших культурних епох.., нагадування про древні (вічні) основи культури» [9, с. 211], мовний знак їі глибинних смислів. У праці Е. Кассірера «Філософія символічних форм» символічна реальність осмислюється як платформа творчої самореалізації, а символ - як втілення людського духу. Реальність культурних смислів засвідчує художній твір як «символічна ланка» [8], що поєднує земне і неземне, предметне та ідеальне і творить живу реальність, яка поза символами існувати не може.

Одним із проявів символу є міф, однак, за твердженням Г.Г. Гадамера, «ми все одно залишаємося позаду непроникної дійсності міфів і їх манливої таїни» [4, с. 242], що простирається поверх нас, продовжуючи своє існування.

Визначаючи конституюючі модуси мистецтва, німецький філософ разом зі «святом» та «символом» актуалізує поняття «гри». Спираючись на філософську концепцію М. Гайдеггера та його поняття «життєвого світу», засновник філософської герменевтики намагається зорієнтувати напрямок теоретизувань у сферу безпосереднього життєвого досвіду, увиразнити взаємозв'язок між філософією і сферою практики, відповісти на питання: «які антропологічні основи нашого сприйняття мистецтва?» [4, с. 287].

Шлях до розкриття смислового потенціалу цього поняття Гадамер вбачає в кількарівневому змістовому полі, що формується навколо нього. Виходячи з цього, слід прояснити основні константи, що визначають суть цього поняття. Відзначимо, що його упровадження дає можливість легітимізувати аспект відкритості філософської системи, концептуалізувати установку наддогматичного схоплення суті та смислу тексту за посередництвом здійснення герменевтичної практики. Метод філософського дослідження, пропонований Г.-Г. Гадамером, передбачає вихід 3 меж теоретичного дискурсу, що існує в якості самозамкненої структури. Стиль і спосіб викладу, варіанти аргументації, а, особливо, характер постано- 
вки питань, як і їх зміст, відображають глибинний взаємозв'язок і співзумовленість сфер теорії та практики. 3 огляду на це, вкажемо на спорідненість філософського осмислення із мистецтвом, що розширює досвідний компонент герменевтики та актуалізує його естетичну складову.

Застосування поняття «гра» до сфери естетичного буття i, зокрема, твору мистецтва, постулює рівноцінність різних модусів людського буття в просторі герменевтичної практики. Твір мистецтва в інтерпретації Г.-Г. Гадамера «відкриває, розгортає свій власний світ» [4, с. 109]. Водночас, він зберігає «самозамкненість», 3 якої «все виходить й куди все повертається» [4, с. 110]. У такому контексті йдеться про перенесення і сприйняття гайдеггерівських понять «світ» і «земля», 3 допомогою яких реалізується деструкція суб' єкт-об'єктних відношень і категоріально-понятійного апарату 3 метою «уникнути упереджень традиційної естетики і сучасного суб' єктивістського мислення» [4, с. 110]. У заданій перспективі поняття «гри» постає виразником, що здатний схоплювати та об'єднувати ці константи як на рівні теоретичного дискурсу, так і в більш широкому просторі мовно-смислових конотацій, вплетених у всеосяжну нерозривну структуру життєвого досвіду і світобуття.

Оскільки «смисл впровадження поняття гри полягає у тому, щоб показати, що тут кожен завжди співучасник» [4, с. 294], стає зрозумілим аспект тлумачення художнього твору в якості «гри» $\mathrm{i}$ шляхом «гри».

Процесуальність і подієвість притаманні грі, «спосіб буття якої - це саморепрезентація» [5, с. 154], спонукає до співучасті та комунікативної активності. Свобода руху, що постулюється «грою», - заради самої свободи та руху, що не вбачає кінцевої точки призначення, змушує пригадати метафоричну знахідку М. Гайдеггера «Holzwege». Самоцінність у бутті «гри» корелює 3 розумінням твору мистецтва - їх смислова канва розкривається в досвіді безпосередньої взаємодії.

У зв'язку з цим доцільно вказати на той аспект, що випливає 3 названих властивостей поняття «гри». Розгортаючись та функціонуючи в якості одного з консолідуючих факторів маркування головних тематичних ліній та елементу з'єднання операційних про- 
цедур, «гра» втілює значущі позиції філософської герменевтики. Варто взяти до уваги те, що завдяки запропонованому Г.-Г. Гадамером трактуванню цього поняття і його включенню у структуру теоретично функціонуючих та методично активних понять, реалізуються основні завдання герменевтики, зокрема у сфері мистецтва. Подібна стратегія обгрунтовує потребу включення до життєвого досвіду досягнень духу, відображених у текстах різних історичних епох.

Взаємопереходи між текстом та його тлумаченням, твором i контекстом, діалектична співпричетність у ланцюгу автор-текстчитач демонструють яскравий приклад того, як смисловий потенціал поняття «гри» розкривається в усіх відношеннях. Проблема буття твору мистецтва, актуалізуючи в теоретичному дискурсі поняття «гра», відбувається шляхом співвіднесення 3 феноменом «виконання», «презентації» художнього твору.

М. Вішке, сучасний дослідник творчості Г.-Г. Гадамера, відзначає: «Безкінечність естетичного досвіду базується на незавершеності твору мистецтва, що породжує цей досвід» [3, с. 57]. Ця теза, заснована на принципах гадамерівського герменевтичного дискурсу, дає можливість зробити кілька важливих висновків. Передусім важливо підкреслити, що поняття «гри» поєднує у собі «безкінечність» і «незавершеність», які корелюють 3 потенційною актуальністю твору мистецтва та здатністю до «розігрування» себе самого як в аспекті буття-для-себе, так і буття-для-інших. Таким чином, гра постає багатоаспектним поняттям, що містить у собі різнорівневі шари герменевтичної теорії.

Актуальність мистецтва, інтерпретованого за посередництвом «гри», вбачається у тому, що характеристики художнього твору як історично детермінованого відходять у контекст інтерпретації і постають тлом його репрезентацій. Надчасова універсальність такого досвіду формує простір для реалізації герменевтичних процедур. Перспектива діалогу 3 художніми текстами різних епох, аналогічна буттю філософії як розмови мислителів крізь століття, зумовлює виникнення герменевтичних ситуацій. Постання в горизонті актуальної присутності різних часових зрізів та їх ахронне сприйняття не руйнує, а лише увиразнює значущість традиції. 
Закріплення «гри» серед визначальних понять філософської герменевтики демонструє роль естетичної складової у цьому проекті. Отже, використання методологічного потенціалу поняття «гра» у межах герменевтичної теорії, зокрема щодо сфери мистецтва, можна вважати продуктивним рішенням Г.-Г. Гадамера. Методологічна цінність «гри» розкривається в ситуації «злиття горизонтів», що відбувається як взаємодія частини і цілого, входження в герменевтичне коло, яке «переплавляє» горизонти, зокрема й часові. Твір мистецтва постає актуальною присутністю, сутність якої в «постійному прирощуванні буття» [5, с. 188].

Таким чином не підлягає сумніву, що поняттям «символ», «гра» та «свято» належить конституююча роль в естетичній концепції Г.-Г. Гадамера. Текстоцентричне розуміння культури зумовлює їх трактування у межах герменевтичної парадигми. Оскільки естетичний аспект $є$ досить важливим для філософської герменевтики, слід підкреслити його онтологічну та методологічну вагу для інтерпретаційної практики, головні риси якої репрезентують поняття «символ», «гра» та «свято». Експлікація герменевтичного досвіду 3 допомогою цих понять дає можливість актуалізувати смислові пласти, які містять у собі основні складові горизонту, що окреслює життєвий світ людини та розкриває досвід буття у світі.

Досвід у трактуванні герменевтики є однією 3 головних і першочергових форм, що породжуються внаслідок взаємодії між буттям людини та світу, тексту та контексту. Зближення на основі герменевтичних настанов «себе» 3 Іншим, аплікація через розуміння в індивідуальний «досвід-Я» досвіду Іншого $є$ співвимірними 3 входженням тексту в новий для нього контекст. Формування людини в межах особистого та колективного життєвого світу дає можливість говорити про конструювання у самосвідомості суб'єкта герменевтичного досвіду метанаративу, сплетеного з різновекторного та багатопланового поєднання текстів різних епох і типів, що, своєю чергою, припускає можливість освоєння нових ареалів культурного поля. Тут доцільно шукати паралелі 3 концептом «топографії Чужого» сучасного німецького продовжувача феноменологічної традиції Б. Вальденфельса. Входження у життєвий світ об'єктів, що набувають рис о-мовленого розуміння через посеред- 
ництво герменевтичного досвіду задає перспективу, з якої в найбільш широкому значенні розгортається принцип культуротворення, засновуючись на якому й існує та примножується весь смисловий масив, який прийнято означувати як традицію.

Намагаючись досягнути онтологічної експлікації мистецтва, Г.-Г. Гадамер не заперечує його матеріалізованих форм, однак відмовляється визнати їх істинним буттям. Саме досвід істини дає можливість артикулювати у герменевтичній площині Г.-Г. Гадамера поняття свята, що є найвищою формою гри, яка допомагає витіснити реальність на інший рівень, де «будь-яка цільова співвіднесеність... не те, що зникає, але своєрідним чином немов витає у повітрі» [5, с. 147]. Г.-Г. Гадамер підкреслює піднесеність свята, його здатність розірвати плетиво повсякденності і вирвати з нього тих, хто прагне стати учасником святкового дійства. Власне гра й слугує онтологічною основою свята. Підкреслюючи його позараціональний характер, мислитель вважає свято одним 3 тих феноменів, що репрезентують актуальний стан культури і мають власний час. У феномені свята реалізована темпоральність буття, а «темпоральна структура свята вищою мірою загадкова» [5, с. 169]. На думку Г.-Г. Гадамера, свято доцільно розглядати крізь призму культурної пам'яті, що дасть можливість зберегти буття культури як цілісний континуум. Важливо, що на відміну від звичайної гри кожне свято центроване ідеєю, і гра може трансформуватися у свято лише тоді, коли починає асоціюватися з певною ідеєю (так, на свято перетворилися Олімпійські ігри).

Прикметною ознакою свята Г.-Г. Гадамер вважає повернення: «Чіткий ритм повторюваності, виокремлення з часового плину, подібне до космічної пульсуючої совісті, приносить звістку про першість часу, про те, що не все у ньому злите в нерозпізнаваному плині і що під час свята відбувається повернення величної миті» [5, с. 159].

Згідно з Г.-Г. Гадамером, свято виконує функцію збирання усіх залучених до нього у певне ціле, співдружність, як це демонструє культ Діоніса.

Дошукуючись відповіді на питання про антропологічні підстави сприймання мистецтва, Г.-Г. Гадамер акцентує увагу на тому, що свято прокладає місток між буденною і сакральною сферами 
буття і $є$ особливим періодом їх безпосереднього інтенсивного контакту, чого не спостерігаємо у повсякденній реальності. І власне у тому святковому коловороті, вічному поверненні до «величної миті» людина знаходить виправдання тому, що вона мимоволі підпорядкувала себе тим правилам, які продиктувало свято як вимогу істини буття.

Таким чином, герменевтичний проект Г.-Г. Гадамера реалізується через естетизацію філософської думки. Модальностями естетичного у герменевтичному досвіді мислителя постають символ, гра і свято. Естетична домінанта творчості мислителя виявляє причетність до «антропологічного повороту», у контексті якого Г.-Г. Гадамер у праці «Актуальність прекрасного» дошукується антропологічних основ нашого сприйняття мистецтва. У зв'язку 3 цим він експлікує роль символічного у культурній самосвідомості західної людини, розгортає ігрову концепцію мистецтва, що, трансформуючись у святкове дійство, постає своєрідним переживанням часу, яке знімає будь-які суперечності як неістотні у плині вічного і прекрасного.

\section{ЛITEPATУРA}

1. Богачов А. Досвід і сенс. Київ : Дух і літера, 2011. 336 с.

2. Бодрийяр Ж. Прозрачность зла / пер. с фр. Л. Любарской, Е. Марковской. Москва : Добросвет, 2000. 258 с.

3. Вишке М. Конечность понимания. Произведение искусства в интерпретации Х.-Г. Гадамера. Исследования по феноменологии и философской герменевтике. Минск : ЕГУ, 2001. С. 55-67.

4. Гадамер Г.-Г. Актуальность прекрасного / пер. с нем. Москва : Искусство, 1991. 367 с.

5. Гадамер Х.-Г. Истина и метод: основы философской герменевтики / пер. с нем. Москва : Прогресс, 1988. 704 с.

6. Инишев И. Н. Феноменологическая герменевтика между теорией языка и теорией действия. Борисов Е. В., Инишев И. Н., Фурс В.Н. Практический поворот в постметафизической философии. Т. 1. Вильнюс : ЕГУ, 2008. С. 10-82.

7. Инишев И. Н. Феноменология как теория образа. Логос. 2010. Т. 78. № 5. С. 196-204. 
8. Кассирер Э. Философия символических форм: В 3-х тт. Москва - Санкт-Петербург : Университетская книга, 2002.

9. Лотман Ю. М. Статьи по семиотике культуры и искусства. Санкт-Петербург : Академический проект, 2002. 544 с.

10. Филимонова И. В. Герменевтика Х.-Г. Гадамера как методология социокультурного действия : дисс. ... канд. философ. наук : 09.00.13 / Ростов-на-Дону, 2003. 158 с.

11. Хайдеггер М. Время и бытие. Москва : Политиздат. 1993. 483 с.

\section{REFERENCES}

Bogachov, A. (2011). Experience and meaning. Kiev: Dukh í lítera. 336 p. [In Ukrainian].

Baudrillard, J. (2000). Transparency of evil. Moscow: Dobrosvet. 258 p. [In Russian].

Vishke, M. (2001). The finitude of understanding. In: A work of art in the interpretation of H.-G. Gadamer. Research in phenomenology and philosophical hermeneutics. Minsk: YEGU, 55-67. [In Russian].

Gadamer, H.-G. (1991). Relevance of the beautiful. Moscow: Iskusstvo. 367 p. [In Russian].

Gadamer, H.-G. (1988). Truth and Method: Foundations of Philosophical Hermeneutics. Moscow: Progress. 704 p. [In Russian].

Inishev, I. N. (2008). Phenomenological hermeneutics between the theory of language and the theory of action. In: Borisov, E. V., Inishev, I. N. \& Furs, V. N. Practical turn in post-metaphysical philosophy. T. 1. Vilnius: YEGU, 10-82. [In Russian].

Inishev, I. N. (2010). Phenomenology as a theory of the image. In: Logos (Logos). V. 78, № 5, 196-204. [In Russian].

Cassirer, E. (2002). Philosophy of symbolic forms: In 3 vols. Moscow St. Petersburg: Universitetskaya kniga. [In Russian].

Lotman, Yu. M. (2002). Articles on the semiotics of culture and art. St. Petersburg: Academic project. 544 p. [In Russian].

Filimonova, I. V. (2003). Hermeneutics H.-G. Gadamer as a methodology of sociocultural action: diss. ... cand. philosopher sciences: 09.00.13. Rostov-naDonu. 158 p. 
Heidegger, M. (1993). Time and Being. Moscow: Politizdat. 483 p. [In Russian].

\title{
Eduard Gnatyuk
}

Assistant of Philosophy Department, National University of Water and Environmental Engineering; Rivne, Ukraine; e-mail: e.m.gnatyuk@nuwm.edu.ua; ORCID: https://orcid.org/0000-0002-4128-2724

\section{Symbol, game and holiday as modalities of esthetic in the context of herme- neutic experience}

\begin{abstract}
The paper researches the evident extension of hermeneutic experience interpreted by H.-G. Gadamer as the way from incomprehension to comprehension and characterized with the duration and procedurality. H.-G. Gadamer denies logic and instrumental interpretation of comprehension presenting it with the ontological plan in the retrospect of which comprehension is characterized as a way of human's being. Basing on M.Heidegger's research concerning with the existence of pre-reflexive structures of the world and their "defining in advance" a thinker presents the version of the "comprehension in advance". This one creates hermeneutic circle together with historical dialectic and defines our involvement in the world and traditions to a greater extent than discursive options. H.-G. Gadamer's hermeneutic experience is equal to the art's experience that is presented as an independent resource of "truth's experience". The research of artistic authenticity criteria requires the appeal to the tradition of fundamental esthetic categories' development where symbol, game and holiday take the first position. For a thinker literary text is interpreted as "being's fragment" that is life's fragment. The author states that it may not possible to see the truth's gleam without this fragment. H.-G. Gadamer provides the coherence between being's fragments using a symbol that collects completeness of human's being within an object image. The paper establishes that Promethean myth, which is characterized as a myth of "European fortune" by H.-G. Gadamer, concerns with all history and culture enriching it with own reminiscences and transforming promethean symbol according to spiritual demands of each epoch. The study reveals that each epoch presents promethean symbol as a heroic ideal of moral freedom and humanity's safer, or as a criminal who shortened the distance of human's improvement. Trans-
\end{abstract} 86

H.Skovoroda Institute of Philosophy of the NAS of Ukraine 
ferring the attention to the "game" demonstrates the implementation of the principle of key relationship of philosophy and practical sphere, different life experience. The application of game's notion according to the sphere of esthetic being interprets the equivalence of different modes of human's existence in the space of hermeneutic practice. The study characterizes art work as an upto-date existence, the core of which deals with the "permanent being's accretion". Therefore, it is evident that symbol, game and holiday make a big constitutive difference in H.-G. Gadamer's esthetic conception.

Keywords: symbol, game, holiday, hermeneutic, esthetic, understanding, hermeneutic experience. 